\title{
FUNCTIONAL BARRIERS TO PROFESSIONAL ACCESS - GENDER EMPOWERMENT AND THE ECONOMICS OF COVER LETTERS
}

\author{
Aadya Kedia \\ Daly College Indore
}

DOI: 10.46609/IJSSER.2020.v05i08.014 URL: https://doi.org/10.46609/IJSSER.2020.v05i08.014

\begin{abstract}
The workforce of India is masculinizing rapidly. India's Female Labour Force Participation Rate has fallen to a historic low of $23.3 \%$. The reduction in employment of women is primarily due to growing mechanization and automation in manufacturing and agriculture. However, access to jobs in the service and professional sectors has been very limited for women which have contributed to the falling rate of employment for women in India. Women in India, especially those from weaker socio-economic backgrounds face multiple structural and social barriers in assessing quality employment- which is a crucial means of achieving socio-economic mobility and emancipation. This paper has determined that the exclusion of women from the workforce traces its origin to larger gender and class-based discrimination that is rampant in Indian workplaces. The lack of access of women to soft skills that have become more important in the service-oriented economy reduces their employability in the formal sector. This paper has also sought to provide recommendations aimed at increasing the accessibility of women to quality employment through the development of communication and soft skills of women and the gender-sensitization of the society as a whole aimed at tackling regressive narratives surrounding women at the workplace.
\end{abstract}

Keywords: Gender, Employment, Discrimination, Woman, Agriculture.

\section{Introduction}

Human Development, which is driven through indicators such as education and skill development, continues to be a challenge for policymakers in India. Even though literacy is considered to be key for socio-economic progress the Indian literacy rate has only grown to $74.04 \%$, according to the 2011 census. Being a developing economy, providing quality education to a population as large as India's has always been a challenge for subsequent governments. However, even beyond the paucity of resources, access to formal education in India is limited by the presence of multiple socio-cultural barriers that unfairly impact different sections of society, 


\section{International Journal of Social Science and Economic Research}

ISSN: $2455-8834$

Volume:05, Issue:08 "August 2020"

most of which have been historically oppressed and marginalized. Access to education is considered to be important not only for the socio-economic development of the nation as a whole but also for generating income and employment opportunities for individuals. Education is considered to be imperative for achieving socio-economic mobility, the absence of which impacts the self-actualization potential of individuals. There exists a wide gender disparity in the literacy rate in India- the effective literacy rates in 2011 were $82.14 \%$ for men and $65.46 \%$ for women (Engleman, 2009).

Research conducted at Harvard University suggests that the unemployment rate amongst women in India is more than double that of men with similar qualifications. About $8.7 \%$ of able-bodied, working-age urban, educated women in the country are unemployed but only $4 \%$ of comparable men find themselves without a job (PTI, 2019). This alludes to the fact that women, even those who are educated continue to face barriers during hiring and recruitment in the Indian job market. Even though discrimination based on gender is illegal under the Indian constitution, an analysis of the discourse surrounding the employment of women in the formal economy by market experts reveals that there is gender discrimination in the hiring process across the India (Kingdon, 2007). Even though patriarchal principles affect organizational hiring practices and work cultures across the world, the problem in India continues to be particularly acute. An Economic Survey of India conducted by the Organization for Economic Cooperation and Development has found that India has the largest difference between the employment rates of women and men amongst all member nations at 52\%. The margin by which India tops this list shows the severity of the problem, given Turkey comes next with a difference of $37 \%$. Developed nations in the world including Sweden and Norway are the best performers with a 5\% difference in the employment rates of men and women (Pandey, 2019). Even though the recent decrease in employment rates for women in India is also representative of the recent economic slowdown faced by the country, the impact of gender on the employability of an individual is imperative to form a holistic and inclusive policy.

Gender, however, is not the only barrier that women in India are made to pass whilst accessing employment. The politics of class also plays a key role in determining the employability of an individual. Command over English is considered to be a very important skill for jobs, especially in the service sector where many women seek employment. Access to learning English continues to be hegemonized by the economically affluent sections of India. Along with other 'soft skills', the ability to develop a proficiency in English is dependent on the economic background of individuals. The employability of women from economically weaker and socially backward backgrounds in the formal economy further decreases due to their lack of access to vocational education and skill development programs (Rukmini, 2019). 


\section{International Journal of Social Science and Economic Research}

ISSN: $2455-8834$

Volume:05, Issue:08 "August 2020"

Informal structures and grassroots level organizations have been the primary source of welfare and skill development for women belonging to weaker socio-economic backgrounds. The 21 st century has been marked by the growth of self-help groups and non-governmental organizations working in the field of skill development in an attempt to make women more employable. Organizations such as SEWA (Self Employed Women's Association), Janodaya and Vimochana have been instrumental in providing means of employment to women directly or indirectly across India.

\section{Background}

Computer and Digital literacy provide knowledge enable individuals to use technology to define and disseminate information. Vernacular literacy is regarded as the acquisition of skills in a language that enables communication. Media literacy entails the ability to access, analyze, evaluate and create messages across a variety of frameworks. Health literacy imparts knowledge and information to the individuals in terms of all the ways that are essential to take care of one's health care needs and requirements. Emotional literacy is the literacy through which individuals acquire an understanding regarding the expression of their emotions. Cultural literacy is required to develop sensitivity to different values, norms, morals, ethics, beliefs, principles and standards. Lastly, moral literacy seeks to develop a comprehensive understanding of morality and ethics (Kaur, 2019). Literacy in school seeks to develop these skills from an academic perspective. Research suggests that the acquisition of knowledge and information in terms of various types of literacies helps individuals to not only carry out their tasks and activities appropriately and efficiently but also to develop morality and ethics that sustain their living conditions appropriately (Kaur, 2019).

Formal education is a prerequisite to achieving literacy. However, the definitions of literacy have also evolved with changes in technological, social and economic environments. The education system of India has tried to evolve and include Digital Media and Health literacy, which are becoming increasingly prevalent in today's economic environment (Kaur, 2019). Even though these changes in curriculum and pedagogy have been made in an attempt to prepare the population of India for changes in demand for labor, the impact of these changes has been limited due to two reasons. Firstly, many communities in India do not have access to formal education due to the presence of social and cultural barriers. Secondly, changes in curriculum and pedagogy have not been implemented in less developed regions of India- primarily due to the paucity of resources and negligence of public officials. This has resulted in the lack of Computer, Vernacular and Visual Literacy within the workforce of India- especially amongst those who reside in less developed and rural regions. This directly impacts the employability of women in key sectors of the economy. 


\section{International Journal of Social Science and Economic Research}

ISSN: $2455-8834$

Volume:05, Issue:08 "August 2020"

Moreover, English as the means of communication in workspaces creates a system of exclusion and marginalization within the country. Fluency in English is endemic of the deep class-based divisions that are characterized by the growing economic inequalities within the country. Research by the Centre for Research and Debates in Development Policy found that only 20\% of the Indian population speaks English, and only 4\% speak the language fluently. Those who speak fluent English earn 34\% higher wages than those who are less fluent (Nagarajan, 2014). Even though the majority of the country (approximately one billion people) does not speak English, it continues to be one of the most crucial determinants of social status, income, prestige, and employment. This implies that $4 \%$ of the country's population can determine, control, and oppress the majority $96 \%$ simply by virtue of knowing English (Bhatia, 2017).

A cover letter is a letter of introduction that is attached to another document such as a résumé or a curriculum vitae is used by job-seekers in applications for employment as a way of introducing themselves to potential employers and explaining their suitability for the desired positions (Yate, 2004). Cover Letters are often the first layer of contact that applicants have with their potential employers, and often guides the kind of interaction that the two parties have in the future and influence the hiring decisions of the employer (Beatty, 2004). The 'Cover Letter' became popular in the 2nd half of the 20th century, as the United States of America started to transition from a manufacturing-oriented to a service-oriented economy. It became significant because a service-oriented economy demanded direct interactions of employees with customers, something that was extremely limited when workers were primarily engaged in manufacturing. Cover Letters emerged as a method of determining the productivity of potential employees in an economy characterized by the continuous evaluation of the workforce by the market (Lurie, 2013). As cover letters have become more popular and abundant in the job market, they have also become a means of perpetuating discrimination based on the identity of individuals. By providing very limited information about candidates, it allows employers to straight jacket individuals into identities which face social discrimination.

\section{Discussion}

Gender Discrimination faced by women in the job market is a barrier to not just individual socioeconomic mobility but is also a hindrance to the feminist movement as it is one of the most prominent barriers to women's emancipation and gender equality. The absence of employment opportunities for women has a direct impact on their level of socio-economic mobility and their ability to make free choices and achieve self-actualization. This discrimination that manifests itself in high unemployment rates for women traces its origins to cultural and religious beliefs and narratives surrounding women. Most communities in India uphold patriarchal beliefs that place the burden of 'homemaking' exclusively on women. With the emergence of the modern economy, the economic value placed on 'homemaking' is negligible which has resulted in 


\section{International Journal of Social Science and Economic Research}

ISSN: $2455-8834$

Volume:05, Issue:08 "August 2020"

women doing a significant part of unpaid labor in India. Moreover, in order to fulfill their socially mandated burden of childrearing and homemaking, women are often forced to stay away from formal structures of employment. The perceptions and narratives that surround women in India often trickle down to the job market and affect the mentality of employers- creating an environment of subliminal gender-based discrimination against women. The very fact that the employment rate for women is half that of men at equal levels of education and qualification is testimony to how skewed the market for employment is against women. The lack of public safety and physical and sexual harassment in the workplace further deter women from accessing employment across the barriers of caste and class. Research suggests that $37.5 \%$ of women in India have missed out on opportunities at the workplace because of the lack of safety in public transportation (Green, et. al., 2004). Moreover, the general organizational culture of companies is inherently masculine and fails to account for gender-specific needs of women including the provision of flexible working hours, menstrual leave and so on.

Overcoming these functional barriers to the employment of women often requires interventions not just from employers (companies) but also from the state. Increasing access to formal education and bettering public safety have been associated with the increasing participation of women in the workforce. Research has determined that the more comfortable women are in their local communities and homes, the more likely they are to pursue employment within that community (Green, et. al., 2004). The development of soft skills amongst women adds to their ability to develop cover letters and $\mathrm{CV}$ s which enables them to present themselves better in front of employers and adds to their employability. The treatment of women in workplaces is a larger reflection of their perception in society. Tackling and dispelling regressive narratives around women and normalizing their presence in the workforce has been found to be imperative in sensitizing the job market to their needs.

The value placed on cover letters increases the propensity of identity-based discrimination. As cover letters have become more popular and abundant in the job market, they have also become a means of perpetuating discrimination based on the identity of individuals. By providing very limited information about candidates, it allows employers to straight jacket individuals into identities which face social discrimination. The basis for this is not limited to gender but often extends to class, caste, and race. Perfecting a cover letter often requires expertise in English, a language alien to the majority of Indians. Moreover, those who have lacked access to formal education structures often lack the resources to develop documents including cover letters and CVs. This creates a cycle of oppression for communities that have historically faced socioeconomic oppression and exclusion. Individuals from the Scheduled Castes and Scheduled Tribe Communities, especially women face social barriers in accessing formal educational structures (Dhesi, 1998). Even if there is the development of vocational and technical skills that are 


\section{International Journal of Social Science and Economic Research}

ISSN: $2455-8834$

Volume:05, Issue:08 "August 2020"

required to perform the core aspects of jobs, employment and hiring are severely affected because of the lack of 'quality' in cover letters. The problem is not just restricted to the lack of access to certain communities to formal education structures but extends to the bias that exists in the minds of employers. Skills such as command over the English language are often given priority over those skills that jobs consist of. The premium placed on the English language leads to the creation of a structure that excludes individuals who have not had accessed it during schooling- primarily because of their class and caste identity. It allows employers to depend more on their preconceived notions and biases with respect to different identities- which leads to the perpetuation of discrimination in a country like India that is characterized by the presence of multiple social hierarchies (Siddique, 2008).

\section{Conclusion}

The challenges faced by women in the job market can be traced to the patriarchal mindset of individuals combined with the inefficiency of the education system when it comes to filling gaps in the process of skill development. Beyond comprehensive social campaigns aimed at redefining the role that women occupy in Indian society and families, there is a need to make the educational system of India more comprehensive, contextual, and relevant. Education should no longer be considered as a short-term project aimed at achieving a certain percentage of literacy but should be conceived as a comprehensive and life-long program that seeks to provide a variety of learning programs to all individuals, including basic literacy, life and livelihood skill development, citizenship development and social and cultural learning programs (Sinha, 2011). Institutional change is often driven by social activism- which has been marked in India with the growth of grassroots level organizations and not for profit initiatives that seek to create a more egalitarian society through advocacy, skill development, and political mobilization. Continued support for these movements and organizations is imperative to create a level playing field in the job market.

Cover Letters are symbolic of how the market perceives an individual. The control over this social perception often determines the economic returns that one receives from the market. There is a need to foster cognizance about the importance of vernacular and soft skills as determinants of employment. The social and economic emancipation of underprivileged women is contingent on the elimination of systematic barriers to employment faced by them. This can be most efficiently achieved through the combined efforts of the government, civil society organizations, grassroots level initiatives, and the public.

\section{Bibliography}




\section{International Journal of Social Science and Economic Research}

ISSN: $2455-8834$

Volume:05, Issue:08 "August 2020"

Beatty, R.H. (2004). The Perfect Cover Letter: Third Edition. John Wiley \& Sons. Accessed on 1st March 2020

Bhatia, S. How English Creates A New Caste System in India. Pacific Standard, 23rd March 2017

Dhesi, A. (1998). Caste,Class Synergies and Discrimination in India. International Journal of Social Economics, Accessed on 3rd March 2020

Engelman, E. (2009). The State of World Population 2009. Accessed on 2nd March 2020

Green, E., Moore, J., Easton, H., Heggie, J. (2004). Barriers to Women's Employment and Progression in the Labour Market in the North East of England. Centre for Social and Policy Research University of Teesside. Accessed on 2nd March 2020

Kaur, A. (2019). Types of Literacy. Accessed on 29th February 2020

Kingdon, G.G. (2007). , The progress of school education in India. Global Poverty Research Group, Economic and Social Research Council. Accessed on 2nd March 2020

Lurie, S. The Cover Letter: A Short History of Every Job-Seeker's Greatest Annoyance. The Atlantic, 11th September 2013

Nagarajan, R. English edge: Those who speak the language fluently 'earn 34\% more than others'. Times of India, 5th January 2014

Pandey, K. India has one of the highest unemployment rates in women. Down to Earth. 5th December 2019

Press Trust of India. Unemployment rate among Indian women more than double of men: Study. Economic Times. 30th August 2019

Rukmini, S. India's workforce is masculinizing rapidly. Livemint. 10th June 2019

Siddique, Z. (2008). Caste Based Discrimination: Evidence and Policy. Institute for the Study of Labor. Accessed on 3rd March 2020

Sinha, S. (2013). Report of the Expert Committee on National Curriculum Framework for Education. Accessed on 4th March 2020

Yate, M.J. (2004). What Is a Cover Letter?". Cover letters that knock 'em dead . Adams Media. Accessed on 1st March 2020 